\title{
Is the Weekend Effect Really a Weekend Effect?
}

\author{
Wing Him Yeung ${ }^{1}$ \\ ${ }^{1}$ Faculty of Business Administration, Lakehead University, Thunder Bay, Canada \\ Correspondence: Wing Him Yeung, Faculty of Business Administration, Lakehead University, Thunder Bay, ON, \\ P7B 5E1, Canada. Tel: 1-807-343-8419. E-mail: whyeung @lakeheadu.ca
}

Received: June 18, 2015

Accepted: June 27, 2015

Online Published: August 25, 2015

doi:10.5539/ijef.v7n9p267

URL: http://dx.doi.org/10.5539/ijef.v7n9p267

\begin{abstract}
The weekend effect, as documented in earlier finance literatures, refers to the tendency in which stock returns are lower on Mondays relative to the other days of the week. This paper confirms and extends the results illustrated in these earlier literatures by showing that the weekend effect exists in the early years and it is beginning to diminish in the recent years. This paper also finds out that the weekend effect is related to the industries in which the firms belong to. In addition, this paper demonstrates that the weekend effect as defined in earlier literatures is in fact a Monday effect rather than a weekend effect.
\end{abstract}

Keywords: weekend effect, efficient market, market anomalies

\section{Introduction}

Are security returns predictable or not? Are security prices reflecting all available information or not? These are common questions being investigated in market efficiency literatures. The efficient market hypothesis states that security prices reflect certain type of information, and the particular type of information depends on the form of the efficient market hypothesis. In particular, the weak-form efficient market hypothesis states that past information is reflected in the security prices, the semi-strong-form efficient market hypothesis says that security prices reflect all publicly available information, and the strong-form efficient market hypothesis asserts that all public and private information is reflected in security prices. The implication is that security prices cannot be predicted from the relevant information as indicated above if the market is efficient.

The early finance literatures focus on whether security returns are predictable from past information, such as past returns. If the market is efficient, then security returns should not be predictable from past information; that is, the security prices should follow a random walk. Nevertheless, some of the early literatures suggest that security returns are predictable from past returns. Fama (1965) investigates whether the security returns of the 30 stocks in the Dow Jones Industrial Average Index are predictable or not from past returns, and the results demonstrate the existence of positive autocorrelation for daily returns of the stocks. In addition to daily returns, there is also evidence suggesting that security returns are predictable for weekly and monthly returns. Lo and MacKinlay (1988) observe positive autocorrelation in weekly returns of New York Stock Exchange (NYSE) stocks, and Fisher (1966) finds evidence of autocorrelation in monthly returns of diversified portfolios. All these literatures suggest that security prices are predictable from past security returns, and the implication is that the efficient market hypothesis may not hold. Nevertheless, some literatures do not agree with the above by stating that either the power of the tests is low or the autocorrelation is not significant in magnitude.

During the period from the 1970's to the 1990's, more literatures begin to focus on the issue of whether security returns are predictable or not. DeBondt and Thaler $(1985,1987)$ test whether security returns are predictable or not by grouping NYSE stocks based on their returns in the past three to five years relative to the market benchmark. In particular, the groups of NYSE stocks that perform the worst and the best in the past three to five years are referred to as "extreme losers" and "extreme winners", respectively. DeBondt and Thaler find that the extreme losers tend to outperform the market in subsequent years and vice versa for the extreme winners. Instead of grouping securities based on their long-term past returns, Jegadeesh and Titman (1993) categorize securities based on their short-term past returns. They find that past winners (securities with the best performance in the past 12 months) have higher returns than past losers (securities with the worst performance in the past 12 months) in the subsequent year. Baker et al. (2011) find that stocks with low volatility have higher future returns relative to those with high volatility in the United States. Dutt and Humphery-Jenner (2013) extend the analysis and 
confirm that the same results apply to stocks in emerging markets and developed markets outside of North America. The above empirical evidence suggests that securities returns can be explained by past returns and volatilities, and it seems like that the market is not as efficient as it may seem.

In addition to the time-series predictability as discussed above, there is also evidence suggesting the existence of cross-sectional predictability. Basu (1977) shows that expected returns can be explained by earnings-to-price ratios. In particular, securities with high earnings-to-price ratios are expected to have higher returns. Banz (1981) finds that the size or market capitalization of a firm has an impact on security returns. It is suggested that smaller firms tend to have higher expected returns. Fama and French (1992) claim that beta in the capital asset pricing model (CAPM) does not have explanatory power; instead, two other factors - size and book-to-market ratio are sufficient to explain security returns.

Finally, a number of literatures suggest that there are seasonal effects in security returns. French (1980) examines whether the abnormal returns of individual securities are correlated with the days of the week. Using daily returns of the Standard and Poor (S\&P) composite portfolio, French shows that the average returns tend to be lower on Monday, while the returns on the other days of the week do not show any specific patterns. The lower returns observed on Mondays are referred to as the weekend effect. Instead of lower Monday returns, Chan et al. (2005) find higher Monday returns for real estate investment trusts (REITs) with higher institutional holdings. In addition to the weekend effect, Keim (1983) investigates the relationship between abnormal monthly returns and the market value of NYSE and American Stock Exchange (AMEX) common stocks. The individual securities are grouped into ten deciles based on their market values. Keim confirms the empirical results in Banz's literature that small-size firms tend to have higher expected returns than large-size firms. Keim further shows that the size effect tends to be related to another effect-the January effect. That is, the high abnormal returns of the small-size firms are concentrated on the first few days of January. All of the above results show that there is predictability in the security prices. Since the above empirical results are not consistent with the efficient market and CAPM, these are referred to as anomalies. However, whether these imply an inefficient market or not remains a question, as the above anomalies can be caused by problems such as incorrect models being used, data snooping, and so on.

Among the anomalies discussed above, this paper is going to investigate the weekend effect further. The weekend effect serves as potential evidence suggesting a violation of the efficient market hypothesis, as returns are predictable from the days of the week. However, what's more interesting and puzzling for the weekend effect is that it is not consistent with the traditional theory. The traditional finance theory states that returns should be higher when risk is higher. Thus, according to the traditional theory, the Monday returns should be higher than the returns on any other days of the week. The reason is that the Monday returns are calculated based on the period from the closing time on Friday to the closing time on Monday. As a result, the Monday returns span over a three-day period. The longer the time period is, the higher the uncertainty involved, which is equivalent to a higher level of risk. However, the weekend effect seems to contradict with the traditional theory because the weekend effect states that the Monday returns are lower rather than higher as implied by the risk level.

There are many literatures investigating on the existing anomalies. Among those, Schwert (2003) shows that the weekend effect exists until 1977, and it seems to have disappeared for the sample period from 1978 to 2002. The purposes of this paper are three-folded. First, this paper confirms and extends Schwert's results by using data from 1928 to 2010. Second, this paper investigates whether the weekend effect is related to the industry that the firms belong to by using the Standard Industrial Classification (SIC) code. Third, French (1980) and Schwert (2003) calculate Monday returns based on the closing price on Fridays and the closing price on Mondays. This paper extends the analysis on the weekend effect by separating the Monday returns as defined above into two parts: the weekend returns and the Monday returns. The weekend returns are defined as the returns based on the closing price on Fridays and the opening price on Mondays, while the Monday returns are referred to as the returns based on the opening price on Mondays and the closing price on Mondays. As a result, this paper looks at whether the weekend effect is actually a weekend effect or a Monday effect. This paper is organized as follows: Section 2 presents the data being used in this paper. Section 3 shows the empirical results obtained by confirming and extending Schwert's paper. Section 4 discusses the methodology used to obtain the main empirical results of this paper, such as whether the weekend effect depends on the industry or not, as well as whether the weekend effect is in fact a weekend effect or a Monday effect. Section 5 analyzes these main empirical results, and section 6 concludes this paper.

\section{Data}

Daily returns of the NYSE/AMEX/NASDAQ portfolio for the period from January 2, 1928 to December 31, 
2010 obtained from the Center for Research in Security Prices (CRSP) are used to confirm and extend Schwert's results in section 3 of this paper. The data used to generate the main empirical results in section 4 and 5 of this paper are obtained from the daily returns of the individual stocks in the Daily Stock file of CRSP for the period from January 2, 1928 to December 31, 2010.

\section{Empirical Results by Confirming and Extending Schwert's (2003) Paper}

Schwert (2003) uses portfolio data based on the Dow Jones Index and the S\&P composite portfolio from 1885 to 2002 and shows that the weekend effect seems to be disappearing in the recent years by running the following regression:

$$
R_{t}=\alpha_{0}+\alpha_{W} \text { Weekend }_{t}+\varepsilon_{t}
$$

$R_{t}$ refers to the daily return of the above portfolio at time $\mathrm{t}$, and Weekend $d_{t}$ is a dummy variable that takes on the value of 1 when the daily return at time t spans a weekend and otherwise 0 . The Monday returns in Schwert's paper are defined as the returns of a security calculated based on the closing prices on Fridays and the closing prices on Mondays. As demonstrated in Table 1, Schwert shows that the coefficient $\alpha_{\mathrm{W}}$ takes on a negative value for the period from 1885 to 1977 . This suggests that security returns are lower on Mondays, and this confirms the weekend effect. However, Schwert also shows that $\alpha_{\mathrm{W}}$ is no longer statistically significant for the sample period between 1978 and 2002. As a result, he concludes that the weekend effect does exist but only for the earlier periods.

Table 1. Results by confirming and extending Schwert's paper

\begin{tabular}{ccccc}
\hline & \multicolumn{4}{c}{ Schwert's (2003) Results } \\
\cline { 2 - 5 } Sample Period & $\alpha_{0}$ & $\mathrm{t}\left(\alpha_{0}=0\right)$ & $\alpha_{\mathrm{W}}$ & $\mathrm{t}\left(\alpha_{\mathrm{W}}=0\right)$ \\
\hline $1885-2002$ & 0.0005 & $8.52^{*}$ & -0.0017 & $-10.13^{*}$ \\
$1928-1952$ & 0.0007 & $3.64^{*}$ & -0.0030 & $-6.45^{*}$ \\
$1953-1977$ & 0.0007 & $6.80^{*}$ & -0.0023 & $-8.86^{*}$ \\
$1978-2002$ & 0.0005 & $4.00^{*}$ & -0.0005 & -1.37 \\
\hline
\end{tabular}

\begin{tabular}{ccccccccc}
\hline & \multicolumn{4}{c}{ Results by Confirming and Extending Schwert's Paper } \\
\cline { 2 - 9 } Sample Period & $\alpha_{0}$ & $\mathrm{t}\left(\alpha_{0}=0\right)$ & $\alpha_{\mathrm{W}}$ & $\mathrm{t}\left(\alpha_{\mathrm{W}}=0\right)$ & $\alpha_{0}$ & $\mathrm{t}\left(\alpha_{0}=0\right)$ & $\alpha_{\mathrm{W}}$ & $\mathrm{t}\left(\alpha_{\mathrm{W}}=0\right)$ \\
\cline { 2 - 9 } & 0.0006 & $7.53^{*}$ & -0.0019 & $-10.33^{*}$ & 0.0013 & $15.56^{*}$ & -0.0027 & $-14.38^{*}$ \\
$1928-2010$ & 0.0006 & $3.58^{*}$ & -0.0028 & $-6.81^{*}$ & 0.0015 & $8.02^{*}$ & -0.0035 & $-7.57^{*}$ \\
$1928-1952$ & 0.0007 & $6.88^{*}$ & -0.0023 & $-10.32^{*}$ & 0.0009 & $9.89^{*}$ & -0.0024 & $-11.36^{*}$ \\
$1953-1977$ & 0.0006 & $4.35^{*}$ & -0.0010 & $-3.36^{*}$ & 0.0013 & $13.08^{*}$ & -0.0025 & $-10.57^{*}$ \\
$1978-2002$ & 0.0004 & 1.18 & -0.0007 & -0.85 & 0.0010 & $2.91^{*}$ & -0.0014 & -1.81 \\
$2003-2010$ & & &
\end{tabular}

Note. This table presents regression results in Schwert's (2003) paper: $\mathrm{Rt}=\alpha 0+\alpha W W e e k e n d t+\varepsilon t$. In addition, this table shows the results by confirming and extending Schwert's paper through the use of daily returns of the NYSE/AMEX/NASDAQ portfolio from January 2, 1928 to December 31, 2010. These results are obtained by using value-weighted data and equal-weighted data. T-statistic with an * refers to those with $95 \%$ significance.

Using daily returns of the NYSE/AMEX/NASDAQ portfolio from January 2, 1928 to December 31, 2010, this paper attempts to confirm Schwert's results up to year 2002, as well as to extend the results to determine whether or not the weekend effect exists during the period from January 1, 2003 to December 31, 2010. Table 1 shows that, based on the entire sample period from 1928 to 2010, the weekend effect exists and is statistically significant. For further analysis, the data are broken down into four different sub-periods: i). 1928-1952; ii). 1953-1977; iii). 1978-2002; and iv). 2003-2010. Table 1 shows similar results as those of Schwert and suggests that the weekend effect is significant for the period up to 1977. The results also suggest that the weekend effect is statistically significant for the period between 1978 and 2002, which is inconsistent with the conclusion of Schwert. Nevertheless, it is clear that the trend is consistent with that of Schwert. That is, the value of the coefficient $\alpha_{\mathrm{W}}$ is getting closer to 0 in recent years, and the results are getting less statistically significant as well. In particular, the weekend effect is not statistically significant anymore in the period between 2003 and 2010. Table 1 also shows that the results are similar regardless of whether the value-weighted or equal-weighted market portfolio is being used. Nevertheless, when the results are obtained by using equal-weighted market portfolio, the weekend effect is more significant. One of the potential explanations is that the weekend effect is 
concentrated in small-size firms. When the market portfolio is equal-weighted, the small-size firms have the same impact as the large-size firms. On the other hand, when the market portfolio is value-weighted, the impact of the small-size firms is lower than that of the large-size firms. If the weekend effect is mostly the result of the small-size firms, then equal-weighted results would show a more significant weekend effect.

Table 2. Two-digit standard industrial classification codes

\begin{tabular}{|c|c|c|c|}
\hline SIC Code & Industry & SIC Code & Industry \\
\hline 01 & Agricultural Production - Crops & 50 & Wholesale Trade - Durable Goods \\
\hline 02 & Agricultural Production - Livestock & 51 & Wholesale Trade - Nondurable Goods \\
\hline 07 & Agricultural Services & 52 & Eating and Drinking Places \\
\hline 08 & Forestry & 53 & General Merchandise Stores \\
\hline 09 & Fishing, Hunting, and Trapping & 54 & Food Stores \\
\hline 10 & Metal Mining & 55 & Automotive Dealers \& Service Stations \\
\hline 12 & Coal Mining & 56 & Apparel and Accessory Stores \\
\hline 13 & Oil and Gas Extraction & 57 & Furniture and Home Furnishings Stores \\
\hline 14 & Nonmetallic Minerals, except Fuels & 58 & Eating and Drinking Places \\
\hline 15 & General Building Contractors & 59 & Miscellaneous Retail \\
\hline 16 & Heavy Construction, except Building & 60 & Depository Institutions \\
\hline 17 & Special Trade Contractors & 61 & Nondepository Institutions \\
\hline 20 & Food and Kindred Products & 62 & Security and Commodity Brokers \\
\hline 21 & Tobacco Products & 63 & Insurance Carriers \\
\hline 22 & Textile Mill Products & 64 & Insurance Agents, Brokers, \& Service \\
\hline 23 & Apparel and Other Textile Products & 65 & Real Estate \\
\hline 24 & Lumber and Wood Products & 67 & Holding and Other Investment Offices \\
\hline 25 & Furniture and Fixtures & 70 & Hotels and Other Lodging Places \\
\hline 26 & Paper and Allied Products & 72 & Personal Services \\
\hline 27 & Printing and Publishing & 73 & Business Services \\
\hline 28 & Chemicals and Allied Products & 75 & Auto Repair, Services, and Parking \\
\hline 29 & Petroleum and Coal Products & 76 & Miscellaneous Repair Services \\
\hline 30 & Rubber and Misc. Plastics Products & 78 & Motion Pictures \\
\hline 31 & Leather and Leather Products & 79 & Amusement \& Recreation Services \\
\hline 32 & Stone, Clay, and Glass Products & 80 & Health Services \\
\hline 33 & Primary Metal Industries & 81 & Legal Services \\
\hline 34 & Fabricated Metal Products & 82 & Educational Services \\
\hline 35 & Industrial Machinery and Equipment & 83 & Social Services \\
\hline 36 & Electronic \& Other Electric Equipment & 84 & Museums, Botanical, Zoological Gardens \\
\hline 37 & Transportation Equipment & 86 & Membership Organizations \\
\hline 38 & Instruments and Related Products & 87 & Engineering \& Management Services \\
\hline 39 & Miscellaneous Manufacturing Industries & 88 & Private Households \\
\hline 40 & Railroad Transportation & 89 & Services \\
\hline 41 & Local and Interurban Passenger Transit & 91 & Executive, Legislative, and General \\
\hline 42 & Trucking and Warehousing & 92 & Justice, Public Order, and Safety \\
\hline 43 & U.S. Postal Service & 93 & Finance, Taxation, \& Monetary Policy \\
\hline 44 & Water Transportation & 94 & Administration of Human Resources \\
\hline 45 & Transportation By Air & 95 & Environmental Quality and Housing \\
\hline 46 & Pipelines, except Natural Gas & 96 & Administration of Economic Programs \\
\hline 47 & Transportation Services & 97 & National Security and International Affairs \\
\hline 48 & Communication & 99 & Nonclassifiable Establishments \\
\hline 49 & Electric, Gas, and Sanitary Services & & \\
\hline
\end{tabular}

Note. This table presents the list of two-digit Standard Industrial Classification (SIC) codes.

Overall, the results in Table 1 confirm the conclusion of French and Schwert in the sense that the weekend effect 
exists. That is, the returns on Mondays are lower than the returns on any other days of the week. However, the results also show that the weekend effect is the most significant in the early and mid-1900's only. The weekend effect seems to be diminishing in the late 1900's, and it is not significant anymore in the early 2000's.

\section{Methodology for Main Empirical Results}

As discussed above, the weekend effect mostly exists in early periods only, and it begins to diminish in recent years. This paper is going to extend the analysis of the weekend effect beyond those of French and Schwert in two ways. First, this paper is going to determine whether or not the weekend effect is related to the industry in which a firm is in. Second, French and Schwert define the Monday returns based on the closing price on Fridays and the closing price on Mondays, and such results do not explain whether the effect is a real weekend effect or just a pure Monday effect. That is, the anomaly can be caused by a lower return during the period between the closing of the market on Friday and the opening of the market on Monday (a weekend effect), or it can be generated by a lower return from the opening of the market on Monday to the closing of the market on Monday (a Monday effect).

To determine whether there is a relationship between the weekend effect and the industry in which a firm belongs to, daily return data of all individual stocks in the Daily Stock file of CRSP for the period between January 1, 1928 and December 31, 2010 are used. Similar to Table 1, the sample period is broken down into four different sub-periods: i). 1928-1952; ii). 1953-1977; iii). 1978-2002; and iv). 2003-2010. The individual securities are grouped by the industries in which they belong to, and such a classification is done by using the two-digit SIC codes. The two-digit SIC codes are listed in Table 2. After the individual securities are grouped into different industry groups, regression (1) is run for each security based on the daily returns. The average values of the coefficients and test statistics for each sub-period are calculated to determine whether the weekend effect exists in all industries or not.

The same data set will be used to determine whether the weekend effect as defined in French and Schwert is actually a weekend effect or a Monday effect. To do so, the weekend returns and the Monday returns are calculated for each individual stock in the Daily Stock file of CRSP. The weekend return is defined as the return based on the closing price on Fridays and the opening price on Mondays. The Monday return is calculated based on the opening price on Mondays and the closing price on Mondays.

Table 3. Regression results of individual stocks

\begin{tabular}{ccccc}
\hline Sample Period & $\boldsymbol{\alpha}_{\mathbf{0}}$ & $\mathbf{t}\left(\boldsymbol{\alpha}_{\mathbf{0}}=\mathbf{0}\right)$ & $\boldsymbol{\alpha}_{\mathrm{W}}$ & $\mathbf{t}\left(\boldsymbol{\alpha}_{\mathrm{W}}=\mathbf{0}\right)$ \\
\hline $\mathbf{1 9 2 8 - 1 9 5 2}$ & 0.0013 & $49.45^{*}$ & -0.0032 & $-49.62^{*}$ \\
$\mathbf{1 9 5 3 - 1 9 7 7}$ & 0.0009 & $53.82^{*}$ & -0.0033 & $-90.86^{*}$ \\
$\mathbf{1 9 7 8 - 2 0 0 2}$ & 0.0017 & $46.40^{*}$ & -0.0019 & $-22.41^{*}$ \\
$\mathbf{2 0 0 3 - 2 0 1 0}$ & 0.0012 & $16.02^{*}$ & -0.0008 & $-4.60^{*}$ \\
\hline
\end{tabular}

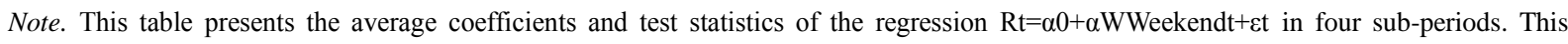
regression uses daily returns of all individual stocks in the Daily Stock file of CRSP from January 2, 1928 to December 31, 2010. T-statistic with an * refers to those with $95 \%$ significance.

\section{Analysis of Main Empirical Results}

Daily returns of the market portfolio are used in section 3 of this paper. Instead of using the market portfolio, daily returns of individual stocks are used in this section. Table 3 shows the results of regression (1) when individual security data are used. The average coefficients and test statistics of the regression of individual stocks are presented for each of the four sub-periods. As the results in Table 3 illustrate, the weekend effect clearly exists in early periods. Nevertheless, the results in Table 3 are different from those in Table 1 in the sense that the weekend effect is still statistically significant in the recent years, from 2003 to 2010. As a result, the existence of the weekend effect seems to depend whether data on market portfolio or individual securities are being used. However, the trend presented in Table 3 is quite similar to that of Table 1. Even though the weekend effect is still present in recent periods, it is getting less significant. The value of the coefficient $\alpha_{\mathrm{W}}$ is closer to 0 in the 2003-2010 time period relative to the earlier periods. Thus, it can be concluded that the weekend effect is more apparent when daily returns of individual stocks rather than those of the market portfolio are used; however, the trend that the weekend effect is getting less significant in time is consistent regardless of the data being used. 
Table 4. Regression results of individual securities grouped by SIC codes

\begin{tabular}{|c|c|c|c|c|c|c|c|c|}
\hline \multirow[b]{2}{*}{ SIC } & \multicolumn{4}{|c|}{ 1928-1952 } & \multicolumn{4}{|c|}{ 1953-1977 } \\
\hline & $\alpha_{0}$ & $\mathrm{t}\left(\alpha_{0}=0\right)$ & $\boldsymbol{\alpha}_{W}$ & $\mathbf{t}\left(\alpha_{W}=0\right)$ & $\alpha_{0}$ & $\mathbf{t}\left(\alpha_{0}=0\right)$ & $\boldsymbol{\alpha}_{W}$ & $\mathbf{t}\left(\alpha_{W}=0\right)$ \\
\hline 1 & 0.0009 & 1.4485 & -0.0014 & -0.9122 & 0.0003 & 0.4706 & 0.0005 & 0.3092 \\
\hline 10 & 0.0015 & $10.742 *$ & -0.0032 & $-9.5882 *$ & 0.0012 & $8.6744^{*}$ & -0.0039 & $-12.1016^{*}$ \\
\hline 12 & 0.0025 & $4.5948^{*}$ & -0.0014 & -1.0632 & 0.0009 & $4.9557^{*}$ & -0.0032 & $-7.7687 *$ \\
\hline 13 & 0.0013 & $9.7262^{*}$ & -0.0041 & $-12.7764 *$ & 0.0012 & $10.7388^{*}$ & -0.0048 & $-19.5342 *$ \\
\hline 14 & 0.0008 & $4.1713^{*}$ & -0.0029 & $-5.8884 *$ & 0.0006 & $2.7021^{*}$ & -0.0036 & $-7.0510 *$ \\
\hline 15 & 0.0026 & $3.2324^{*}$ & -0.0010 & -0.5109 & 0.0001 & 0.1004 & -0.0027 & -1.0526 \\
\hline 16 & 0.0012 & $3.679 *$ & -0.0034 & $-4.1167 *$ & 0.0007 & $3.2959^{*}$ & -0.0040 & $-8.0488^{*}$ \\
\hline 17 & -- & -- & -- & -- & -0.0024 & -1.0538 & -0.0037 & -0.6945 \\
\hline 20 & 0.0011 & $10.6479^{*}$ & -0.0024 & $-9.5429 *$ & 0.0007 & $11.5249^{*}$ & -0.0021 & $-16.3729 *$ \\
\hline 21 & 0.0008 & $4.4797^{*}$ & -0.0022 & $-5.1364 *$ & 0.0007 & $5.3810^{*}$ & -0.0017 & $-5.4494 *$ \\
\hline 22 & 0.0014 & 7.3986* & -0.0028 & $-6.2306^{*}$ & 0.0007 & $6.6154 *$ & -0.0027 & $-10.9452 *$ \\
\hline 23 & 0.0011 & $5.3052^{*}$ & -0.0029 & $-5.6670 *$ & 0.0010 & $6.0709 *$ & -0.0031 & $-8.5198 *$ \\
\hline 24 & 0.0015 & $4.1059^{*}$ & -0.0043 & $-4.8927 *$ & 0.0015 & $5.3012^{*}$ & -0.0038 & $-5.8224 *$ \\
\hline 25 & 0.0013 & $3.0665^{*}$ & -0.0034 & $-3.3318 *$ & 0.0007 & $2.6858^{*}$ & -0.0022 & $-3.8607 *$ \\
\hline 26 & 0.0012 & $8.1057^{*}$ & -0.0023 & $-6.2858 *$ & 0.0007 & $9.0167 *$ & -0.0027 & $-14.4209 *$ \\
\hline 27 & 0.0010 & $4.7486^{*}$ & -0.0035 & $-6.7076^{*}$ & 0.0008 & $4.6706^{*}$ & -0.0026 & $-6.9303 *$ \\
\hline 28 & 0.0010 & $11.0378^{*}$ & -0.0027 & $-12.6257^{*}$ & 0.0010 & $15.4254^{*}$ & -0.0036 & $-25.1937 *$ \\
\hline 29 & 0.0013 & $12.9289^{*}$ & -0.0033 & $-12.8993 *$ & 0.0009 & $10.9552 *$ & -0.0038 & $-21.6538 *$ \\
\hline 30 & 0.0015 & $6.9368^{*}$ & -0.0039 & $-7.5315^{*}$ & 0.0009 & $5.9488^{*}$ & -0.0032 & $-9.4081 *$ \\
\hline 31 & 0.0016 & $4.6536^{*}$ & -0.0029 & $-3.4972 *$ & 0.0004 & 1.8664 & -0.0009 & -1.7421 \\
\hline 32 & 0.0008 & $6.3661 *$ & -0.0022 & $-6.8598^{*}$ & 0.0007 & $6.8647^{*}$ & -0.0029 & $-13.0784 *$ \\
\hline 33 & 0.0012 & $15.7099^{*}$ & -0.0036 & $-18.7746^{*}$ & 0.0010 & $15.3132 *$ & -0.0044 & $-30.0494 *$ \\
\hline 34 & 0.0013 & $11.7907 *$ & -0.0038 & $-13.7206^{*}$ & 0.0008 & $10.1413^{*}$ & -0.0032 & $-17.8812 *$ \\
\hline 35 & 0.0013 & $14.6842 *$ & -0.0034 & $-16.0528^{*}$ & 0.0009 & $15.8306^{*}$ & -0.0038 & $-29.4439 *$ \\
\hline 36 & 0.0012 & $10.8034 *$ & -0.0033 & $-12.0058^{*}$ & 0.0010 & $13.2459^{*}$ & -0.0043 & $-24.2323 *$ \\
\hline 37 & 0.0012 & $15.6779 *$ & -0.0035 & $-19.2085^{*}$ & 0.0011 & $15.5619^{*}$ & -0.0043 & $-26.9131 *$ \\
\hline 38 & 0.0011 & $6.1149 *$ & -0.0025 & $-5.5598 *$ & 0.0010 & $9.0054 *$ & -0.0040 & $-16.4396^{*}$ \\
\hline 39 & 0.0010 & $4.2993^{*}$ & -0.0026 & $-4.5128 *$ & 0.0007 & $4.1183^{*}$ & -0.0028 & $-7.2524 *$ \\
\hline 40 & 0.0024 & $15.9398^{*}$ & -0.0049 & $-13.4139^{*}$ & 0.0010 & $12.6307^{*}$ & -0.0054 & $-29.2436^{*}$ \\
\hline 41 & 0.0017 & $3.9071^{*}$ & -0.0009 & -0.8500 & 0.0015 & $2.6554^{*}$ & -0.0016 & -1.2513 \\
\hline 42 & 0.0014 & $2.3692^{*}$ & -0.0019 & -1.2954 & 0.0006 & $2.0528^{*}$ & -0.0015 & $-2.1743^{*}$ \\
\hline 44 & 0.0024 & $4.0692^{*}$ & -0.0033 & $-2.2532^{*}$ & 0.0006 & $2.4949^{*}$ & -0.0020 & $-3.7998 *$ \\
\hline 45 & 0.0013 & $7.4231^{*}$ & -0.0049 & $-11.9295^{*}$ & 0.0011 & $7.8083^{*}$ & -0.0048 & $-14.9736^{*}$ \\
\hline 46 & -0.0011 & -0.9641 & -0.0031 & -1.1479 & 0.0005 & 1.1599 & 0.0004 & 0.4990 \\
\hline 47 & 0.0016 & $2.9628^{*}$ & -0.0034 & $-2.6072 *$ & 0.0014 & $4.2082 *$ & -0.0043 & $-5.9587 *$ \\
\hline 48 & 0.0008 & 5.9224* & -0.0027 & $-8.1836^{*}$ & 0.0009 & $6.1848^{*}$ & -0.0035 & $-10.5199 *$ \\
\hline 49 & 0.0009 & $10.8404 *$ & -0.0028 & $-13.4939^{*}$ & 0.0005 & $13.5738 *$ & -0.0014 & $-16.8061 *$ \\
\hline 50 & 0.0014 & $5.7940^{*}$ & -0.0031 & $-5.1519 *$ & 0.0008 & $4.3767^{*}$ & -0.0027 & $-6.5930 *$ \\
\hline 51 & 0.0007 & $4.3774^{*}$ & -0.0026 & $-6.2787 *$ & 0.0006 & $4.2745^{*}$ & -0.0025 & $-7.5388^{*}$ \\
\hline 52 & -- & -- & -- & -- & 0.0007 & 0.5974 & -0.0060 & $-2.1655^{*}$ \\
\hline 53 & 0.0010 & $7.6345^{*}$ & -0.0026 & $-7.9866^{*}$ & 0.0006 & $7.6138^{*}$ & -0.0021 & $-11.1885^{*}$ \\
\hline 54 & 0.0010 & $3.7099^{*}$ & -0.0025 & $-3.9326^{*}$ & 0.0005 & $4.1358^{*}$ & -0.0020 & $-6.6280 *$ \\
\hline 55 & 0.0011 & $2.2211^{*}$ & -0.0022 & -1.8684 & 0.0007 & 1.6439 & -0.0027 & $-2.7814^{*}$ \\
\hline 56 & 0.0009 & $3.2260^{*}$ & -0.0017 & $-2.5077^{*}$ & 0.0006 & $3.6654^{*}$ & -0.0018 & $-5.1421^{*}$ \\
\hline 57 & 0.0018 & $3.0614^{*}$ & -0.0003 & -0.2118 & 0.0004 & 1.0997 & -0.0013 & -1.4898 \\
\hline 58 & 0.0006 & $2.2449^{*}$ & -0.0011 & -1.6455 & 0.0008 & $2.6328^{*}$ & -0.0023 & $-3.4888^{*}$ \\
\hline 59 & 0.0014 & $3.0553^{*}$ & -0.0021 & $-1.9661 *$ & 0.0007 & $4.0740^{*}$ & -0.0020 & $-4.9403 *$ \\
\hline 60 & 0.0005 & $2.6129 *$ & -0.0017 & $-3.6026^{*}$ & 0.0004 & $2.0711^{*}$ & -0.0014 & $-2.7611^{*}$ \\
\hline 61 & 0.0009 & $4.2395^{*}$ & -0.0021 & $-4.0432 *$ & 0.0006 & $4.2317^{*}$ & -0.0025 & $-7.2617^{*}$ \\
\hline 62 & 0.0024 & 1.9562 & 0.0005 & 0.1577 & 0.0013 & $2.9998^{*}$ & -0.0042 & $-4.3293 *$ \\
\hline 63 & 0.0004 & 1.8500 & -0.0020 & $-3.5574 *$ & 0.0006 & $2.6022^{*}$ & -0.0021 & $-4.0960^{*}$ \\
\hline 65 & 0.0021 & $5.5909^{*}$ & -0.0060 & $-6.4834^{*}$ & 0.0012 & $4.3884^{*}$ & -0.0052 & $-8.1507 *$ \\
\hline 67 & 0.0015 & $11.8777^{*}$ & -0.0041 & $-13.3366^{*}$ & 0.0006 & $7.7312 *$ & -0.0024 & $-12.7722 *$ \\
\hline
\end{tabular}




\begin{tabular}{lllllllll}
\hline 70 & 0.0012 & $3.4147^{*}$ & -0.0024 & $-2.8567^{*}$ & 0.0013 & $4.5564^{*}$ & -0.0045 & $-6.8327^{*}$ \\
73 & 0.0018 & $5.0872^{*}$ & -0.0027 & $-3.1931^{*}$ & 0.0012 & $4.3374^{*}$ & -0.0033 & $-5.0344^{*}$ \\
75 & 0.0009 & $2.2275^{*}$ & -0.0015 & -1.6218 & 0.0007 & $2.2438^{*}$ & -0.0028 & $-3.8034^{*}$ \\
78 & 0.0019 & $4.9861^{*}$ & -0.0039 & $-4.3056^{*}$ & 0.0012 & $6.3005^{*}$ & -0.0035 & $-8.3352^{*}$ \\
79 & 0.0017 & $2.8523^{*}$ & -0.0042 & $-2.9498^{*}$ & 0.0030 & $4.0626^{*}$ & -0.0084 & $-5.1806^{*}$ \\
89 & 0.0015 & $2.9920^{*}$ & -0.0064 & $-5.3367^{*}$ & 0.0010 & $3.3951^{*}$ & -0.0032 & $-4.7333^{*}$ \\
99 & 0.0057 & $2.0069^{*}$ & -0.0081 & -1.1653 & 0.0010 & $2.1791^{*}$ & -0.0027 & $-2.6715^{*}$ \\
\hline
\end{tabular}

Table 4. Continue

\begin{tabular}{|c|c|c|c|c|c|c|c|c|}
\hline \multirow[b]{2}{*}{1} & \multicolumn{4}{|c|}{ 1978-2002 } & \multicolumn{4}{|c|}{ 2003-2010 } \\
\hline & 0.0011 & $2.9010^{*}$ & -0.0023 & $-2.6287 *$ & 0.0005 & 1.2415 & 0.0014 & 1.5386 \\
\hline 2 & 0.0001 & 0.1033 & 0.0028 & 1.0189 & 0.0008 & 1.1207 & 0.0016 & 1.0307 \\
\hline 7 & 0.0016 & $2.6145^{*}$ & -0.0049 & $-3.5389 *$ & 0.0014 & 0.0899 & 0.0718 & $2.0436^{*}$ \\
\hline 8 & 0.0027 & 1.3384 & -0.0002 & -0.0520 & 0.0010 & 1.2221 & 0.0058 & $3.2293 *$ \\
\hline 9 & 0.0020 & 1.1984 & -0.0007 & -0.1933 & 0.0017 & 1.3919 & 0.0007 & 0.2555 \\
\hline 10 & 0.0045 & $11.6421^{*}$ & -0.0046 & $-5.1345^{*}$ & 0.0022 & $14.2488^{*}$ & -0.0032 & $-8.9464 *$ \\
\hline 11 & 0.0009 & 0.6177 & -0.0053 & -1.5159 & -- & -- & -- & -- \\
\hline 12 & 0.0011 & $2.7462 *$ & -0.0007 & -0.8298 & 0.0014 & $3.4939^{*}$ & -0.0006 & -0.7071 \\
\hline 13 & 0.0036 & $4.4811 *$ & -0.0027 & -1.4951 & 0.0015 & $5.9304 *$ & -0.0003 & -0.5193 \\
\hline 14 & 0.0034 & $2.1377^{*}$ & -0.0034 & -0.9257 & 0.0007 & 1.5508 & -0.0010 & -1.0515 \\
\hline 15 & 0.0017 & 6.12268 & -0.0008 & -1.2893 & 0.0010 & $4.1507^{*}$ & -0.0027 & $-5.0546^{*}$ \\
\hline 16 & 0.0016 & $5.5552 *$ & -0.0024 & $-3.6335 *$ & 0.0015 & $3.2218^{*}$ & -0.0009 & -0.8673 \\
\hline 17 & 0.0021 & $3.9415^{*}$ & -0.0030 & $-2.3916^{*}$ & 0.0007 & 0.3584 & 0.0089 & $2.0140^{*}$ \\
\hline 20 & 0.0013 & $10.9917 *$ & -0.0009 & $-3.4127 *$ & 0.0008 & $8.6488^{*}$ & -0.0004 & -2.0021 \\
\hline 21 & 0.0009 & $2.1540^{*}$ & -0.0006 & -0.6416 & 0.0010 & $4.7604 *$ & -0.0014 & $-3.0715^{*}$ \\
\hline 22 & 0.0009 & $4.7657^{*}$ & -0.0022 & $-5.0557^{*}$ & 0.0022 & $2.1779 *$ & -0.0018 & -0.7787 \\
\hline 23 & 0.0026 & $4.8522 *$ & -0.0033 & $-2.7211^{*}$ & 0.0007 & $3.6537^{*}$ & -0.0011 & $-2.4575^{*}$ \\
\hline 24 & 0.0011 & $4.1420 *$ & -0.0010 & -1.6527 & 0.0006 & $2.4141 *$ & -0.0013 & $-2.3362 *$ \\
\hline 25 & 0.0010 & $5.4258^{*}$ & -0.0016 & $-3.9742 *$ & 0.0005 & $2.9316^{*}$ & -0.0008 & $-2.0504^{*}$ \\
\hline 26 & 0.0007 & $3.3574 *$ & -0.0006 & -1.1937 & 0.0131 & 1.2202 & -0.0135 & -0.5473 \\
\hline 27 & 0.0012 & $9.0251 *$ & -0.0018 & $-5.8426^{*}$ & 0.0010 & $4.6669^{*}$ & -0.0013 & $-2.8199 *$ \\
\hline 28 & 0.0017 & $19.7082 *$ & -0.0020 & $-10.4672 *$ & 0.0020 & $9.5254^{*}$ & -0.0012 & $-2.5170 *$ \\
\hline 29 & 0.0006 & $4.3284^{*}$ & -0.0004 & -1.3684 & 0.0006 & $3.9127^{*}$ & 0.0006 & 1.6236 \\
\hline 30 & 0.0014 & $7.6858 *$ & -0.0013 & $-3.0051 *$ & 0.0009 & $4.2055^{*}$ & -0.0001 & -0.3917 \\
\hline 31 & 0.0012 & $4.8261 *$ & -0.0014 & $-2.3020 *$ & 0.0010 & $4.4055^{*}$ & -0.0011 & $-2.1425^{*}$ \\
\hline 32 & 0.0007 & $4.0415^{*}$ & -0.0009 & $-2.3072 *$ & 0.0012 & $2.2213^{*}$ & 0.0003 & 0.2944 \\
\hline 33 & 0.0008 & $6.1198^{*}$ & -0.0016 & $-5.3146^{*}$ & 0.0014 & $8.1679 *$ & -0.0005 & -1.4244 \\
\hline 34 & 0.0019 & 8.63218 & -0.0019 & $-3.8299 *$ & 0.0014 & $5.9812^{*}$ & -0.0001 & -0.2090 \\
\hline 35 & 0.0017 & $15.5012 *$ & -0.0016 & $-6.3350 *$ & 0.0013 & $9.7974 *$ & -0.0005 & -1.8648 \\
\hline 36 & 0.0022 & $14.8734 *$ & -0.0029 & $-8.5454 *$ & 0.0015 & $12.9093 *$ & -0.0004 & -1.7282 \\
\hline 37 & 0.0015 & $5.0222 *$ & -0.0015 & $-2.1668 *$ & 0.0014 & $2.7195^{*}$ & -0.0017 & -1.3941 \\
\hline 38 & 0.0024 & $18.5643^{*}$ & -0.0021 & $-7.1115^{*}$ & 0.0016 & $11.9501^{*}$ & -0.0015 & $-4.8949 *$ \\
\hline 39 & 0.0018 & $8.2364 *$ & -0.0029 & $-5.7521 *$ & 0.0013 & $3.6910^{*}$ & -0.0017 & $-2.0620 *$ \\
\hline 40 & 0.0011 & $3.6459 *$ & -0.0016 & $-2.2786^{*}$ & 0.0010 & $5.4482 *$ & -0.0008 & $-2.0445^{*}$ \\
\hline 41 & 0.0019 & $2.5753^{*}$ & -0.0005 & -0.2708 & 0.0016 & $2.1755^{*}$ & 0.0010 & 0.6505 \\
\hline 42 & 0.0011 & $6.6076^{*}$ & -0.0018 & $-4.4402 *$ & 0.0011 & $2.8075^{*}$ & -0.0007 & -0.8748 \\
\hline 44 & 0.0013 & $5.2506^{*}$ & -0.0023 & $-4.0874 *$ & 0.0010 & $4.6540 *$ & -0.0015 & $-3.2252 *$ \\
\hline 45 & 0.0011 & $5.4119 *$ & -0.0016 & $-3.4717 *$ & 0.0020 & $2.8106^{*}$ & -0.0026 & -1.6212 \\
\hline 46 & 0.0007 & $4.1713 *$ & -0.0009 & $-2.3822 *$ & 0.0004 & 1.6010 & 0.0007 & 1.4219 \\
\hline 47 & 0.0017 & $5.2786^{*}$ & -0.0031 & $-4.2830 *$ & 0.0008 & $2.4335^{*}$ & -0.0010 & -1.3744 \\
\hline 48 & 0.0015 & $6.2460 *$ & -0.0016 & $-2.8719 *$ & 0.0016 & $5.5510^{*}$ & 0.0002 & 0.4370 \\
\hline 49 & 0.0007 & $8.4033^{*}$ & -0.0006 & $-3.3918^{*}$ & 0.0005 & $6.2420 *$ & 0.0004 & $2.8649 *$ \\
\hline 50 & 0.0022 & $10.9758^{*}$ & -0.0028 & $-6.1731 *$ & 0.0013 & $8.2032 *$ & -0.0006 & -1.7013 \\
\hline 51 & 0.0018 & 9.7494* & -0.0021 & $-4.8609 *$ & 0.0011 & $5.8846^{*}$ & -0.0006 & -1.5141 \\
\hline 52 & 0.0013 & $3.6682 *$ & -0.0019 & $-2.3304 *$ & 0.0003 & 0.8087 & -0.0008 & -0.9684 \\
\hline
\end{tabular}




\begin{tabular}{|c|c|c|c|c|c|c|c|c|}
\hline 53 & 0.0008 & $4.0632 *$ & -0.0006 & -1.3614 & 0.0012 & $5.1355^{*}$ & -0.0009 & -1.8435 \\
\hline 54 & 0.0013 & $2.7886^{*}$ & -0.0016 & -1.4750 & 0.0006 & $3.3190 *$ & -0.0000 & -0.1442 \\
\hline 55 & 0.0018 & $2.6501 *$ & 0.0002 & 0.1467 & 0.0012 & $4.7278^{*}$ & -0.0012 & $-2.1489^{*}$ \\
\hline 56 & 0.0013 & $5.2436^{*}$ & -0.0016 & $-2.8765^{*}$ & 0.0009 & $6.1496^{*}$ & -0.0011 & $-3.2744^{*}$ \\
\hline 57 & 0.0019 & $3.2890 *$ & -0.0018 & -1.3526 & 0.0008 & $2.9716^{*}$ & -0.0004 & -0.7212 \\
\hline 58 & 0.0020 & $8.1116^{*}$ & -0.0018 & $-3.1620^{*}$ & 0.0009 & $4.3711^{*}$ & 0.0001 & 0.1226 \\
\hline 59 & 0.0014 & $9.6858 *$ & -0.0021 & $-6.1380^{*}$ & 0.0013 & $3.7359 *$ & -0.0009 & -1.2026 \\
\hline 60 & 0.0012 & $30.8556^{*}$ & -0.0013 & $-14.6945^{*}$ & 0.0009 & $4.9781 *$ & -0.0017 & $-4.1605 *$ \\
\hline 61 & 0.0016 & $6.5585^{*}$ & -0.0022 & $-3.8986^{*}$ & 0.0010 & $3.6898^{*}$ & -0.0002 & -0.4592 \\
\hline 62 & 0.0018 & $10.0527 *$ & -0.0018 & $-4.2811 *$ & 0.0014 & $8.4125^{*}$ & -0.0025 & $-6.6300^{*}$ \\
\hline 63 & 0.0009 & $12.5487 *$ & -0.0008 & $-4.8381^{*}$ & 0.0008 & $8.0546^{*}$ & -0.0006 & $-2.5052 *$ \\
\hline 64 & 0.0010 & $3.1779 *$ & -0.0011 & -1.5553 & 0.0008 & $3.3428 *$ & -0.0011 & $-2.1713^{*}$ \\
\hline 65 & 0.0017 & $4.8369 *$ & 0.0000 & 0.0251 & 0.0012 & 1.3683 & 0.0023 & 1.1988 \\
\hline 66 & 0.0051 & 1.0602 & 0.0067 & 0.6057 & -- & -- & -- & -- \\
\hline 67 & 0.0005 & $7.0661 *$ & -0.0002 & -1.1671 & 0.0004 & $10.1534 *$ & -0.0005 & $-6.5399 *$ \\
\hline 70 & 0.0023 & $3.8026^{*}$ & -0.0033 & $-2.4070^{*}$ & 0.0008 & $4.4166^{*}$ & -0.0008 & -1.9426 \\
\hline 71 & 0.0086 & 0.8348 & 0.0275 & 1.1610 & -- & -- & -- & -- \\
\hline 72 & 0.0013 & $3.2727^{*}$ & 0.0008 & 0.8391 & 0.0010 & $2.6607 *$ & 0.0006 & 0.7308 \\
\hline 73 & 0.0023 & $24.1758^{*}$ & -0.0036 & $-16.3004 *$ & 0.0018 & $16.9753^{*}$ & -0.0007 & $-3.0314 *$ \\
\hline 75 & 0.0024 & $4.4062 *$ & -0.0029 & $-2.3143^{*}$ & 0.0014 & $3.2273^{*}$ & -0.0020 & $-2.0426^{*}$ \\
\hline 76 & 0.0006 & 0.9082 & -0.0029 & -1.8651 & -- & -- & -- & -- \\
\hline 78 & 0.0047 & $6.1825 *$ & -0.0040 & $-2.2666^{*}$ & 0.0021 & 1.7983 & 0.0001 & 0.0412 \\
\hline 79 & 0.0022 & $6.9531 *$ & -0.0016 & $-2.1761^{*}$ & 0.0010 & 1.7310 & 0.0007 & 0.6082 \\
\hline 80 & 0.0025 & $12.5752 *$ & -0.0031 & $-6.7021^{*}$ & 0.0012 & $8.7074 *$ & -0.0012 & $-3.9807^{*}$ \\
\hline 81 & 0.0063 & 1.9708 & -0.0037 & -0.5100 & 0.0006 & 0.9474 & 0.0006 & 0.4114 \\
\hline 82 & 0.0046 & 1.7807 & -0.0037 & -0.6218 & 0.0016 & $4.4544^{*}$ & -0.0013 & -1.6403 \\
\hline 83 & 0.0014 & $3.4993 *$ & -0.0021 & $-2.3532 *$ & 0.0022 & $5.5171^{*}$ & -0.0025 & $-2.8207^{*}$ \\
\hline 86 & -0.0002 & -0.0443 & 0.0322 & $2.8887^{*}$ & -0.0003 & -0.2886 & -0.0019 & -0.8755 \\
\hline 87 & 0.0021 & $10.6432 *$ & -0.0023 & $-5.1586^{*}$ & 0.0016 & $6.5539^{*}$ & -0.0009 & -1.6696 \\
\hline 89 & 0.0021 & $4.2846^{*}$ & -0.0038 & $-3.4000^{*}$ & 0.0007 & 1.0300 & 0.0034 & $2.1539^{*}$ \\
\hline 93 & -0.0002 & -0.0800 & 0.0073 & 1.0493 & -- & -- & -- & -- \\
\hline 95 & 0.0023 & $2.0255^{*}$ & -0.0045 & -1.7465 & 0.0088 & 1.8403 & -0.0126 & -1.1537 \\
\hline 96 & -0.0043 & -1.4209 & -0.0050 & -0.7715 & -- & -- & -- & -- \\
\hline 99 & 0.0145 & $2.2655^{*}$ & -0.0167 & -1.1450 & 0.0004 & $2.6017 *$ & -0.0001 & -0.3005 \\
\hline
\end{tabular}

Note. This table presents the average coefficients and test statistics of the regression $R_{t}=\alpha_{0}+\alpha_{W}$ Weekend $d_{t}+\varepsilon_{t}$ in four sub-periods. This regression uses daily returns of all individual stocks in the Daily Stock file of CRSP from January 2, 1928 to December 31, 2010. The results are presented by first grouping the individual stocks by their SIC codes. T-statistic with an * refers to those with $95 \%$ significance.

Table 5. Average weekend returns and monday returns of individual securities

\begin{tabular}{cccc}
\hline & & 1928-1952 & Previous Closing to \\
& $\begin{array}{c}\text { Previous Closing to } \\
\text { Current Closing Returns }\end{array}$ & $\begin{array}{c}\text { Current Opening to } \\
\text { Current Opening Returns }\end{array}$ & $\begin{array}{c}\text { Closing Returns } \\
\text { Volume }\end{array}$ \\
\hline Monday & -0.0019 & 0.0005 & -0.0022 \\
Tuesday & -0.0004 & -0.0003 & -0.0001 \\
Wednesday & 0.0016 & 0.0009 & 0.0009 \\
Thursday & 0.0018 & 0.0014 & 0.0005 \\
Friday & 0.0010 & 0.0009 & 0.0002 \\
\hline & & & $2,273.01$ \\
\hline & & $\mathbf{1 9 5 3 - 1 9 7 7}$ & $2,325.21$ \\
\hline Previous Closing to & Previous Closing to & $2,285.76$ \\
\hline Current Closing Returns & Current Opening Returns & Current Closing Returns \\
Tuesday & -0.0024 & 0.0001 & -0.0025 \\
Wednesday & -0.0005 & -0.0005 & 0.0001 \\
Thursday & 0.0012 & 0.0006 & 0.0006 \\
Friday & 0.0010 & 0.0008 & 0.0002 \\
\hline
\end{tabular}




\begin{tabular}{|c|c|c|c|c|}
\hline & \multicolumn{4}{|c|}{$\begin{array}{r}1978-2002 \\
\end{array}$} \\
\hline & $\begin{array}{c}\text { Previous Closing to } \\
\text { Current Closing Returns }\end{array}$ & $\begin{array}{c}\text { Previous Closing to } \\
\text { Current Opening Returns }\end{array}$ & $\begin{array}{c}\text { Current Opening to } \\
\text { Current Closing Returns }\end{array}$ & Volume \\
\hline Monday & -0.0002 & 0.0011 & -0.0007 & $213,342.19$ \\
\hline Tuesday & 0.0004 & 0.0011 & -0.0002 & $232,660.90$ \\
\hline Wednesday & 0.0014 & 0.0009 & 0.0010 & $244,269.98$ \\
\hline Thursday & 0.0018 & 0.0011 & 0.0013 & $241,652.49$ \\
\hline \multirow[t]{3}{*}{ Friday } & 0.0031 & 0.0012 & 0.0024 & $230,721.94$ \\
\hline & \multicolumn{4}{|c|}{ 2003-2010 } \\
\hline & $\begin{array}{c}\text { Previous Closing to } \\
\text { Current Closing Returns }\end{array}$ & $\begin{array}{c}\text { Previous Closing to } \\
\text { Current Opening Returns }\end{array}$ & $\begin{array}{c}\text { Current Opening to } \\
\text { Current Closing Returns }\end{array}$ & Volume \\
\hline Monday & 0.0004 & 0.0015 & -0.0008 & $869,884.70$ \\
\hline Tuesday & 0.0011 & 0.0007 & 0.0007 & $940,262.86$ \\
\hline Wednesday & 0.0013 & 0.0006 & 0.0010 & $959,021.61$ \\
\hline Thursday & 0.0011 & 0.0011 & 0.0002 & $971,726.57$ \\
\hline Friday & 0.0013 & 0.0006 & 0.0010 & $932,908.86$ \\
\hline
\end{tabular}

Note. This table presents the average Monday returns as defined in French (1980) and Schwert (2003), as well as the weekend returns and the Monday returns as defined in this paper, for individual securities from the Daily Stock file of CRSP. The average trading volume is also presented in this table.

Using the same set of data and methodology, the weekend effect is being analyzed further in this paper by first grouping the individual securities based on the industries they belong to. Table 4 shows the regression results for each sub-period grouped by the SIC codes. Consistent with the results in Table 3, the weekend effect is statistically significant in the early periods for almost all of the industries. Nevertheless, the results are different in the recent years. The weekend effect is only statistically significant for fewer than half of the industries from 2003 to 2010. On the other hand, the coefficient $\alpha_{\mathrm{W}}$ is positive for some of the industries for the recent period, and five of those are statistically significant. This suggests that the security returns are actually higher on Monday for those five industries. Table 4 also shows that there are a few industries that do not experience a weekend effect for most or all of the sample periods. Industries with SIC code 41 (Local and Interurban Passenger Transit) and 57 (Furniture and Home Furnishings Stores) do not experience any weekend effect throughout the entire sample period, while there does not seem to be a weekend effect for industries with SIC code 1 (Agricultural Production-Crops), 15 (General Building Contractors), 46 (Pipelines, except Natural Gas), and 99 (Nonclassifiable Establishments) for most of the sample period. All of the above provide evidence suggesting a relationship between the weekend effect and the industry in which a firm is in.

The final analysis of this paper is to determine whether the weekend effect as defined in French and Schwert is actually a weekend effect or a Monday effect as defined earlier in this paper. The weekend returns and the Monday returns are calculated for each individual security in the Daily Stock file of CRSP from January 2, 1928 to December 31, 2010. Table 5 presents the average Monday returns as defined in French and Schwert (Friday closing to Monday closing returns), the average weekend returns as defined in this paper (Friday closing to Monday opening returns), the average Monday returns as defined in this paper (Monday opening to Monday closing returns), and the average trading volume.

Based on the definition of French and Schwert, the Monday returns are negative in the early periods as illustrated in Table 5. The returns are also negative for Tuesdays but the magnitude is less negative than that of Mondays. Thus, in addition to the weekend effect, there seems to be a Tuesday effect as well in the early periods. However, further research needs to be done in order to confirm the Tuesday effect, as the effect could be the result of holidays on Mondays or nonsynchronous trading. Nevertheless, consistent with previous results, the negative returns on Mondays and Tuesdays disappear recently.

Table 5 also shows whether the weekend effect as defined in French and Schwert is actually a weekend effect or a Monday effect as defined earlier in this paper. As illustrated in Table 5, the weekend returns based on the Friday closing prices and Monday opening prices are positive for all sub-periods. On the other hand, the Monday returns based on the Monday opening prices and Monday closing prices are negative for all sub-periods, even for the most recent years. This result suggests that it is very important to separate the weekend returns from the Monday returns. It is not the weekend returns that are resulting in the so-called weekend effect; rather, it is the Monday returns that are causing the anomaly. As a result, it is in fact a Monday effect rather than a weekend effect. This finding is actually consistent with the traditional theory, that is, the weekend returns should be higher 
as more uncertainty is involved over the weekend.

Finally, it is interesting to investigate whether the anomaly is due to abnormal levels of trading volume on a particular day of the week. The average trading volume, defined as the average number of shares being traded in one day, is presented for all days of the week in Table 5, and the results demonstrate that the trading volume remains quite consistent throughout all days of the week. As a result, there does not seem to be any evidence that the trading volume is a cause of the anomaly.

\section{Conclusion}

Market efficiency literatures focus on whether stock prices are predictable or not. Many literatures are arguing against the efficient market through different forms of anomalies. Among those, French (1980) finds out that the security returns on Mondays are lower than those on any other days of the week, and this anomaly is referred to as the weekend effect. This is a puzzling effect because if the market is efficient, then security returns should follow the random walk, and so returns should not be predictable. In addition, the weekend returns should be higher than any other days of the week because more days are spanned over the weekend. This longer time period should mean a higher level of uncertainty, and so a higher return should be expected, as opposed to the lower returns being observed on Mondays. Although Schwert (2003) confirms the existence of the weekend effect in the early periods, he finds out that the weekend effect is beginning to diminish in the recent years.

This paper first confirms and extends the results of Schwert by using data from 1928 to 2010. In addition, by using daily returns of individual securities rather than those of market portfolios, further analysis is being done on the weekend effect. This paper demonstrates that the existence of the weekend effect depends on the industries in which the firms belong to. The weekend effect does exist for most industries, especially for the early periods. However, there are some industries that do not exhibit the weekend effect for all or most of the sample periods. In addition, there are some industries that show a totally opposite result from the weekend effect. That is, the results are higher on Mondays for the firms in those industries. Thus, further research should be done to investigate such an industry effect further.

Finally, this paper shows that the weekend effect is in fact a Monday effect. The weekend returns are positive, and it is the Monday returns that are causing the so-called weekend effect. Such a finding is important because this is more consistent with the traditional theory. Since a longer period is spanned over the weekend, a higher return should be expected with the higher level of uncertainty, and this is being confirmed by the empirical results of this paper. More importantly, this paper demonstrates that the Monday effect is still present even in the recent years. This is a very different result from the one demonstrated by Schwert. As a result, it may not be the case that the weekend effect is diminishing in the recent years. Rather, such findings may just be the result of an incorrectly defined weekend effect. If the weekend effect is defined differently as in this paper, it is clear that this anomaly still exists.

\section{References}

Banz, R. W. (1981). The relationship between return and market value of common stocks. Journal of Financial Economics, 9, 3-18. http://dx.doi.org/10.1016/0304-405X(81)90018-0

Basu, S. (1977). Investment performance of common stocks in relation to their price-earnings ratios: A test of the efficient market hypothesis. Journal of Finance, 32, 663-682. http://dx.doi.org/10.1111/j.1540-6261.1977.tb01979.x

Baker, M., Bradley, B., \& Wurgler, J. (2011). Benchmarks as limits to arbitrage: Understanding the low-volatility anomaly. Financial Analysts Journal, 67, 40-54. http://dx.doi.org/10.2469/faj.v67.n1.4

Chan, S. H., Leung, W. K., \& Wang, K. (2005). Changes in REIT structure and stock performance: Evidence from the Monday stock anomaly. Real Estate Economics, 33, 89-120. http://dx.doi.org/10.1111/j.1080-8620.2005.00113.x

DeBondt, W. F. M., \& Thaler, R. H. (1985). Does the stock market overreact? Journal of Finance, 40, 793-805. http://dx.doi.org/10.1111/j.1540-6261.1985.tb05004.x

DeBondt, W. F. M., \& Thaler, R. H. (1987). Further evidence on investor overreaction and stock market seasonality. Journal of Finance, 42, 557-581. http://dx.doi.org/10.1111/j.1540-6261.1987.tb04569.x

Dutt, T., \& Humphery-Jenner, M. (2013). Stock return volatility, operating performance and stock returns: International evidence on drivers of the 'low volatility'anomaly. Journal of Banking \& Finance, 37(3), 999-1017. http://dx.doi.org/10.1016/j.jbankfin.2012.11.001

Fama, E. F. (1965). The Behavior of Stock Market Prices. Journal of Business, 38, 34-105. 
http://dx.doi.org/10.1086/294743

Fama, E. F., \& French, K. R. (1992). The cross-section of expected stock returns. Journal of Finance, 47, 427-465. http://dx.doi.org/10.1111/j.1540-6261.1992.tb04398.x

Fisher, L. (1966). Some new stock-market indexes. Journal of Business, 39, 191-225. http://dx.doi.org/10.1086/294848

French, K. R. (1980). Stock returns and the weekend effect. Journal of Financial Economics, 8, 55-69. http://dx.doi.org/10.1016/0304-405X(80)90021-5

Jegadeesh, N., \& Titman, S. (1993). Returns to buying winners and selling losers: Implications for stock market efficiency. Journal of Finance, 48, 65-91. http://dx.doi.org/10.1111/j.1540-6261.1993.tb04702.x

Keim, D. B. (1983). Size-related anomalies and stock return seasonality. Journal of Financial Economics, 12, 13-32. http://dx.doi.org/10.1016/0304-405X(83)90025-9

Lo, A. W., \& MacKinlay, A. C. (1988). Stock market prices do not follow random walks: Evidence from a simple specification test. Review of Financial Studies, 1, 41-66. http://dx.doi.org/10.1093/rfs/1.1.41

Schwert, G. W. (2003). Anomalies and market efficiency. In G. M. Constantinides, M. Harris, \& R. M. Stulz (Eds.), Handbook of the Economics of Finance (pp. 939-974). Elsevier.

\section{Copyrights}

Copyright for this article is retained by the author(s), with first publication rights granted to the journal.

This is an open-access article distributed under the terms and conditions of the Creative Commons Attribution license (http://creativecommons.org/licenses/by/3.0/). 